1993

\title{
Four Clovis Points from San Augustine County, Texas
}

Kenneth M. Brown

Unknown

Follow this and additional works at: https://scholarworks.sfasu.edu/ita

Part of the American Material Culture Commons, Archaeological Anthropology Commons, Environmental Studies Commons, Other American Studies Commons, Other Arts and Humanities Commons, Other History of Art, Architecture, and Archaeology Commons, and the United States History Commons

Tell us how this article helped you.

This Article is brought to you for free and open access by the Center for Regional Heritage Research at SFA ScholarWorks. It has been accepted for inclusion in Index of Texas Archaeology: Open Access Gray Literature from the Lone Star State by an authorized editor of SFA ScholarWorks. For more information, please contact cdsscholarworks@sfasu.edu. 


\section{Four Clovis Points from San Augustine County, Texas}

Creative Commons License

(c) (i) (8)

This work is licensed under a Creative Commons Attribution-NonCommercial 4.0 International License 


\title{
FOUR CLOVIS POINTS FROM \\ SAN AUGUSTINE COUNTY, TEXAS
}

by

Kenneth M. Brown

\begin{abstract}
Four surface-collected Clovis points (two complete, two fragmentary) from the northeastern valley margin of the Angelina River in San Augustine County are described. One specimen is made from Manning fused glass and is the oldest artifact known to have been made of that rock type. The others appear to be made of chert from the Edwards Plateau.
\end{abstract}

\section{INTRODUCTION}

Four Clovis points found on the surface in southern San Augustine County, Texas, are described here. These specimens are in the collection of Dr. Russell Long, a resident of Beaumont, and the specimen numbers used here are those assigned by him. Dr. Long has kindly made the points available for study, although I have not had the opportunity to visit the collection localities in his company. All four came from a relatively restricted area at the south edge of San Augustine County and were found on high ground forming the northern valley margin of the Angelina River, well above the Quaternary terrace deposits that now lie drowned by Sam Rayburn Reservoir. The bedrock here consists of the Eocene Cadell Formation.

One specimen (number 19) came from a ridge (now known as Cadell Island) projecting into the Angelina River valley; according to Dr. Long, a large spring existed here, and the former river channel lay about $2.5 \mathrm{~km}$ to the south. The other three were found nearby in the Lucas Creek drainage, about $4 \mathrm{~km}$ north of the river; a large spring reportedly existed here, also. There are no sites recorded in either of these localities at the Texas Archeological Research Laboratory (TARL), although the nearby W.W. Carroll site (41SA90) was recorded by R.L. Stephenson in 1948; several springs were reported below that site. One tract south of Lucas Creek and east of Cadell Island has been surveyed by U.S. Forest Service archeologists (Ippolito 1983:Figure 17). According to Dr. Long, both the Cadell and Lucas Creek localities are unreported multi-component sites.

Few Clovis points have been reported from San Augustine County. Meltzer (1987:Table 3) reports one specimen. Story et al. (1990:Table 44) report one specimen from Harvey Creek, which is the next major south-draining tributary entering upstream from the Cadell Island locality, about $3.3 \mathrm{~km}$ to the northwest. According to the sketch in the TARL files, it is a complete point about $10.4 \mathrm{~cm}$ long. Another specimen was 
reportedly collected from 41SA57, near the mouth of Attoyac Bayou (Bob Skiles, personal communication).

At least three Clovis points have been found at sites along the southwest valley margin, in Angelina County. One was recorded in 1948 by Stephenson from a private collection made at 41AG37; the sketch in the TARL files indicates it is also a complete point, about $10.3 \mathrm{~cm}$ long, with a blunt tip. This locality is about $14.6 \mathrm{~km}$ south-southeast of the Lucas Creek locality and at about the same elevation as the Cadell Island locality. Another was found at 41AG56, due south of the Cadell locality and also at about the same elevation; it is made of grayish-brown chert. Another specimen, made of fossilized wood, was collected farther upriver at 41AG75 (Bob Skiles, personal communication).

Specimen 759, found at the Lucas Creek locality, is of special interest because it is made of fused volcanic glass from the Manning Formation, and it is the oldest artifact known to have been made of this kind of lithic material (previously, the oldest known artifacts made of Manning fused glass were San Patrice points). The surface exposure of the Manning Formation trends east-west in this area, and ends on the opposite side of the Angelina River valley, about $8.5 \mathrm{~km}$ southwest of the Lucas Creek locality.

Manning fused glass is a natural glass, formed when combustion of lignite beds in the lower Manning Formation fused and partially melted the overlying silica-rich tuff and tuffaceous siltstone deposits. The temperature of fusion is estimated to be more than $1125^{\circ}$ C (King and Rodda 1962). It is similar to the Fort Union fused glass and porcellanite found in south-central Montana and northern Wyoming (Fredlund 1976) and to fused rock termed "clinker" from the Smoking Hills Formation on the Cape Bathurst Peninsula in Canada's Northwest Territories (Le Blanc 1991). All of these were prehistoric sources of knappable stone, and both the Fort Union and Smoking Hills varieties were heavily used in their respective regions (95 percent of lithic material in south-central Montana, according to Fredlund [1976:210]; 74.2 percent of tools and 70.3 percent of modified flakes from sites on the Cape Bathurst Peninsula according to Le Blanc [1991:272]). A Goshen point made of porcellanite, found at the Carter/Kerr-McGee site in Wyoming, indicates this rock type was known by early Paleoindian knappers (Frison 1991a:45-46 and Figure 2.18a). The Fort Union source is especially widespread on the northern Plains. Fissures or vents are associated with these formations, providing an important source of oxygen to the combustible substrate. Fused glass from the Manning Formation, however, although transported rather widely on both sides of the linear Manning outcrop, was apparently never used in quantity except in the immediate vicinity of the exposures. Manning fused glass accounted for about 60-70 percent of chipping debris from the surface of the Chalk Creek \#1 site, but little more than 2 percent of the surface and excavated sample from the 
George C. Davis site (Brown 1976:196, 201 and Figure 3). Many of the sites where fused glass artifacts have been found have only one or two small flakes of the material in the collection.

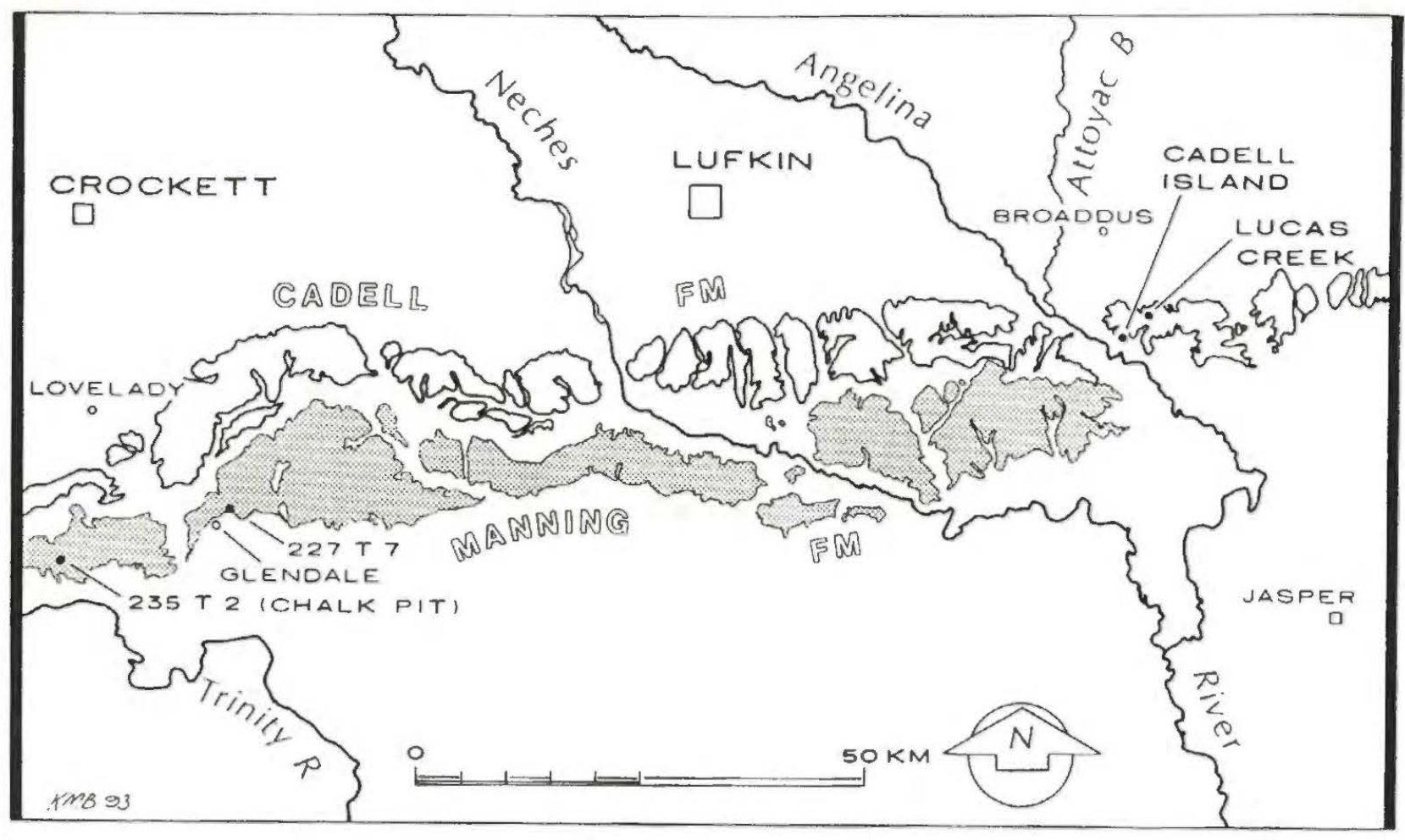

Figure 1. Regional Geology. Outcrops of the Cadell Formation (on which the Clovis points were found, unshaded) and the Manning Formation (shaded) are shown. The Cadell Island and Lucas Creek localities appear at the right side of the figure, while the nearest known sources of fused rocks in the Manning Formation are shown at the left side of the figure. Locality T7 is in Trinity County; the Chalk Pit, locality T2, is in Walker County.

So far as I am aware, the only known outcrops of fused rocks in the Manning Formation remain the seven localities originally reported 30 years ago by King and Rodda. These localities extend from Fayette County in the southwest to Trinity County in the northeast. The latter is about $94 \mathrm{~km}$ west-southwest from the Angelina River localities discussed here (Figure 1). Banks (1990:54) reports finding some of the material at Eagle Hill, on Peason Ridge in Sabine Parish, Louisiana (roughly $87 \mathrm{~km}$ to the east-northeast), although no mention is made of it in Heinrich's (1987) extensive petrologic study. According to Banks (personal communication), the material was not abundant, and occurred as flakes and small chunks with heavy hydration rinds, evidently introduced from some other locality. Manning fused glass is therefore a rather cryptic and esoteric kind of raw material, highly restricted in distribution (although since the Manning Formation 
outcrops on the opposite side of the Angelina River valley, the possibility exists that unreported sources of fused rocks might exist not far away).

All four of these specimens were checked under ultraviolet light by Michael Collins (shortwave, $254 \mathrm{~nm}$, and long wave, $366 \mathrm{~nm}$ ). The Manning fused glass specimen fluoresces a deep salmon or terracotta color. The three chert specimens fluoresce a light yellowish-orange color that is characteristic of Edwards Plateau chert from Central Texas (Hofman et al. 1991). Of these three, specimens 19 and 760 show fluorescence that is, according to Collins, "classical" for Edwards chert, while specimen 758 has a weaker response, especially under shortwave radiation, but is still probably Edwards chert.

\section{DESCRIPTION OF THE SPECIMENS}

conventions for orientation and measurement

The face bearing the catalog number is arbitrarily designated the obverse face. Note that this differs from the procedure of Callahan (1979). When a particular face is described, the terms "left edge" and "right edge" are used as they would apply with that face toward the viewer; where no face is specified, the terms apply as if the obverse face were being viewed. Note that for complete specimens, flute lengths are measured from a line tangent to the basal corners. For fragments, only the longest surviving length of the flute can be measured. "Maximum flute-to-flute thickness" is a measurement that has not been applied to fluted points before. It is simply the maximum thickness of the point measured with the caliper points placed in the flutes at their deepest concavity. Since the flute on one face is generally longer than that on the other face, this location is usually at the end of the shortest flute. If Clovis points were hafted in split wooden mainshafts or split foreshafts similar to the Archaic period examples that have been recovered from dry rockshelters, this dimension corresponds to the thickness of the hafting notch on the distal end of the foreshaft. If, as some people think, Clovis points were hafted in composite bone foreshafts, then the flute-to-flute thickness is probably irrelevant. This dimension is not quite the same as the "hafting flute thickness" measured by Judge (1973:Figure 20), because his measurement was taken at an arbitrary location defined as half of the basal width. Edge angles were measured with a goniometer ruled in $1^{\circ}$ increments. Because there is so much variation in sectional shape at different places along an edge, and even at different distances from the edge at a single location, I do not regard these measurements as very representative. 


\section{Specimen 19 (Cadell Island; Figure 2A-C)}

This complete point is the largest of the four. The distal end has been reworked, and the original length was undoubtedly greater. On the obverse face, reworking of the right edge extends to within $33.0 \mathrm{~mm}$ of the proximal end and to within $31.7 \mathrm{~mm}$ on the left. The flute on the reverse face extends beyond these limits of reworking, so if the foreshaft extended as far as the flute termination, it might have been removed when the point was reworked. The specimen is made from chert with a fairly glossy, light grayish $\tan$ (approximately 5 YR 7.5/1.5) surface patina, but inspection of two small, recent edge nicks shows that the underlying chert is a medium gray, fine-grained but non-vitreous chert, probably from the Edwards Plateau as indicated by ultraviolet fluorescence. The patina is thick and the core colors cannot be accurately recorded. Patina is homogeneous over both the original and reworked parts of the point. It is noteworthy that even deeply patinated Edwards chert will readily fluoresce (Michael Collins, personal communication).

This specimen has the blunt tip and maximum width forward of the midpoint typical of resharpened specimens (Howard 1990:257). The un-reworked segments of the lateral edges are straight to very slightly concave. Both lateral edges and the base are moderately ground. Grinding can be felt and seen under magnification, and stops where resharpening begins, but the transition is neither abrupt nor obvious.

Obverse face (Figure 2A)

The original lateral thinning scars are mostly expanding in shape; some are parallelsided or contracting. Their length ranges from $2.30-8.75 \mathrm{~mm}$ (truncated by a flute), with maximum widths of 1.6-6.05 mm. They are parallel and transversely oriented. Some scars left by reworking are larger and less rippled, and oriented obliquely (although still at right angles to the modified edge). These are up to $15.30 \mathrm{~mm}$ long and $9.50 \mathrm{~mm}$ wide. The obverse face was fluted last, and has what appears to be two successive, overlapping central flute scars. The first flute was apparently well-centered, but the knapper then moved slightly to the left and removed another channel flake slightly to the left of the center. A small nick in the basal edge may correspond to this removal, perhaps from removing a basal nipple. Both flute scars are about the same length and both end in a shallow step fracture.

The right margin of the first flute has been removed by a narrow converging scar (maximum width $5.18 \mathrm{~mm}$; length $15.18 \mathrm{~mm}$ ) originating from the base. The left side of the second flute has a small basal thinning scar with a converging shape, but it appears to predate and to be intruded by the second flute. Its place in the fluting sequence is unclear, except that it seems to precede the second flute. The basal edge has a series of very small 


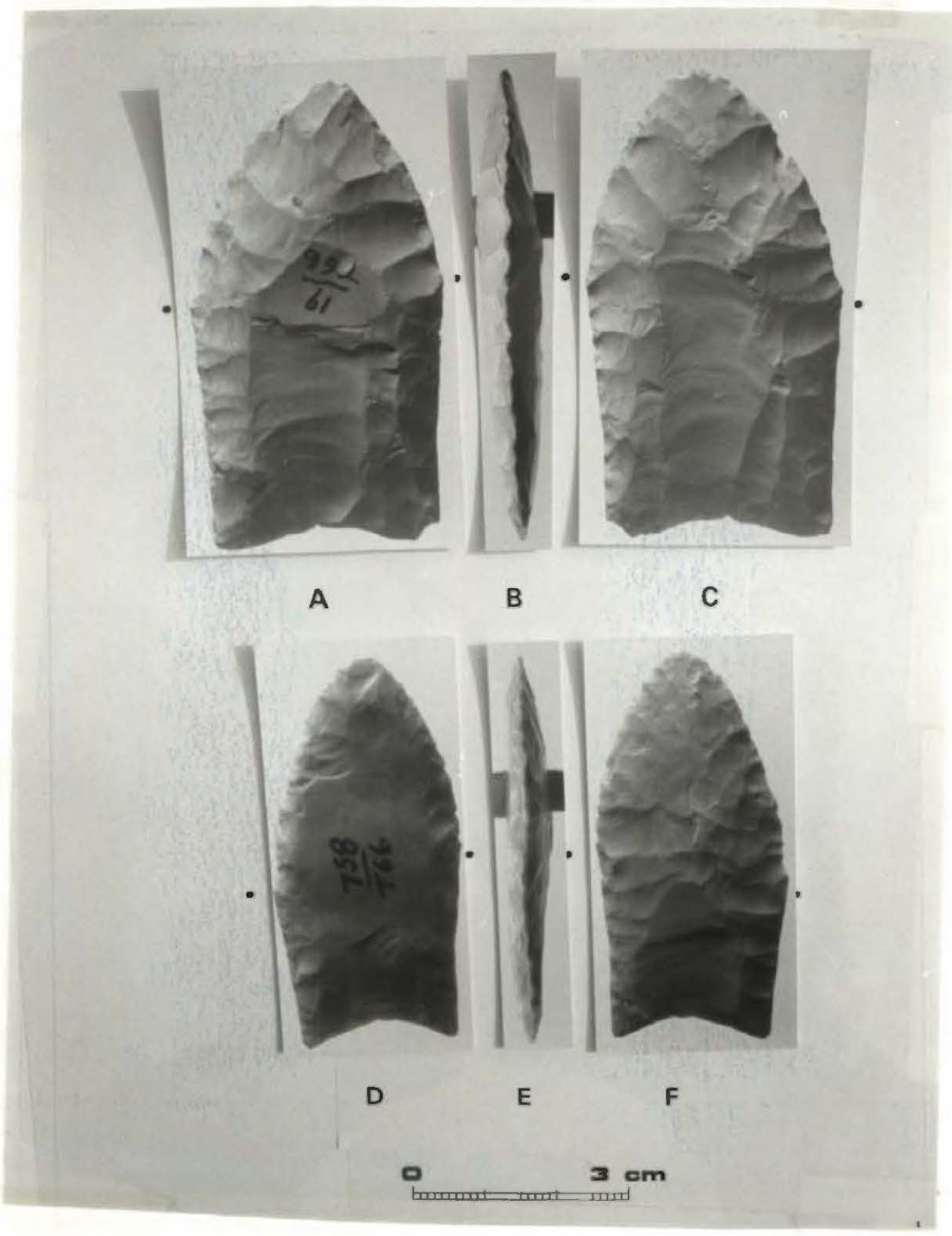

Figure 2. Clovis Points from Cadell Island and Lucas Creek. A, Specimen 19 obverse; B, Specimen 19 profile (obverse face to left); C, Specimen 19 reverse; D, Specimen 758 obverse; E, Specimen 758 profile (obverse face to left); F, Specimen 758 reverse. Dots indicate extent of edge grinding. 
(about 0.6-1.5 mm wide, 0.4-1.5 mm long) pressure flake scars of petaloid shape, their origins truncated by basal grinding.

At the end of the flute on this face is the remnant of a lateral thinning scar that reached from the left edge past the midline of the point, to perhaps 80 percent of the way toward the right edge. It has been truncated by the flutes and by reworking scars. This scar was at least $26.5 \mathrm{~mm}$ long, plunging toward the opposite edge.

Reverse face (Figure 2C)

The lateral thinning scars on this face are nostly expanding, some are parallelsided, and a few are contracting in shape. Their length ranges from 2.85-11.15 mm; maximum width $2.40-8.50 \mathrm{~mm}$. Scars left by reworking are larger, up to $13.75 \mathrm{~mm}$ long and $8.55 \mathrm{~mm}$ wide. This face has the initial flute, which is well centered and has a feathered termination that has been truncated by reworking. The basal end of the flute has been removed by a series of basal trimming scars about 4.7-6.2 mm long, created either to set up a platform for the flute on the opposite face, or to even the basal edge. This flute is flanked on either side by long $(19.8 \mathrm{~mm})$, narrow $(2.5-6.2 \mathrm{~mm})$, parallel-sided to contracting basal scars that were produced after the flute and have removed the proximal halves of its left and right margins.

\section{Modification}

Both faces show moderate polishing, both on the unaltered and reworked areas. Polish occurs both in flake scar hollows and on ridges. The un-reworked edges are ground. Reworked edges are fairly heavily step-fractured, and show moderate rounding, probably from edge scrubbing. One basal comer has been removed by a recent break.

maximum length: $57.94 \mathrm{~mm}$ maximum width: $33.15 \mathrm{~mm}$ maximum thickness: $8.70 \mathrm{~mm}$ maximum flute-to-flute thickness: $6.42 \mathrm{~mm}$ length from base to point of maximum width: $31.30 \mathrm{~mm}$ length from base to point of maximum thickness: $36.45 \mathrm{~mm}$ basal width: $29.76 \mathrm{~mm}$ depth of basal indentation: $1.40 \mathrm{~mm}$ left edge angles: original: $50^{\circ}$ reworked: $40^{\circ}$ right edge angles: original: $71^{\circ}$ reworked: $46^{\circ}$

weight: 17.6 grams obverse face: 
maximum length of flute: $25.95 \mathrm{~mm}$ (flute lengths for all specimens measured from a line tangent to the basal corners, not from the basal indentation) maximum width of flute: $15.58 \mathrm{~mm}$ flute scars: 2 ? grinding on left edge: $31.10 \mathrm{~mm}$ from the base grinding on right edge: $34.15 \mathrm{~mm}$ from the base

Center point of flute origin is $13.6 \mathrm{~mm}$ from left edge, $15.4 \mathrm{~mm}$ from right

reverse face:

maximum length of flute: $36.80 \mathrm{~mm}$ (end removed by reworking) maximum width of flute: $14.83 \mathrm{~mm}$ flute scars: 3 ?

\section{Specimen 758 (Lucas Creek; Figure 2D-F)}

This small Clovis point is made from a light gray (4Y 6.5/1) fossiliferous chert with a fairly vitreous luster. Abundant small (most $0.4 \mathrm{~mm}$ or less in diameter) diatoms or other poorly preserved fossils are visible. Like the previous specimen, this one also appears to have been reworked. The basal parts of the lateral edges are straight to slightly concave. Reworking of the distal end has left it slightly asymmetrical, so that the present tip is now oriented slightly away from the original long axis of the point. It is well thinned, but somewhat blunt in outline. This specimen is nearly identical in size and shape to a specimen of brown chert from Kincaid Rockshelter (Collins et al. 1989:Figure 1f).

On the left edge (obverse face up), grinding is continuous and well developed, ending abruptly where reworking begins. On the right edge, grinding is less pronounced and is almost discontinuous; it is well developed only on edge projections, nearly disappearing in reentrants. As a result, the transition to the reworked edge is not so abrupt. Basal grinding is also present.

This point illustrates a characteristic of Clovis points addressed by Howard (1990:257), namely the retention of large facets on finished points (see also specimen 760). The obverse face has a large, smooth, slightly concave facet that actually covers most of the face (Figure 3). Ripple marks are so indistinct that the direction of wave propagation cannot be determined with certainty --possibly the distal end of the point may correspond to the distal end of the fracture (?). On the reverse face, reworking and lateral thinning are much more extensive, but a small remnant of a smooth facet with no discernible ripple marks lies at the distal end of the flute. The origin of this facet is unknown.

\section{Obverse face (Figure 2D)}

On this face, both lateral edges are rather steeply beveled at an angle of about $45^{\circ}$ 


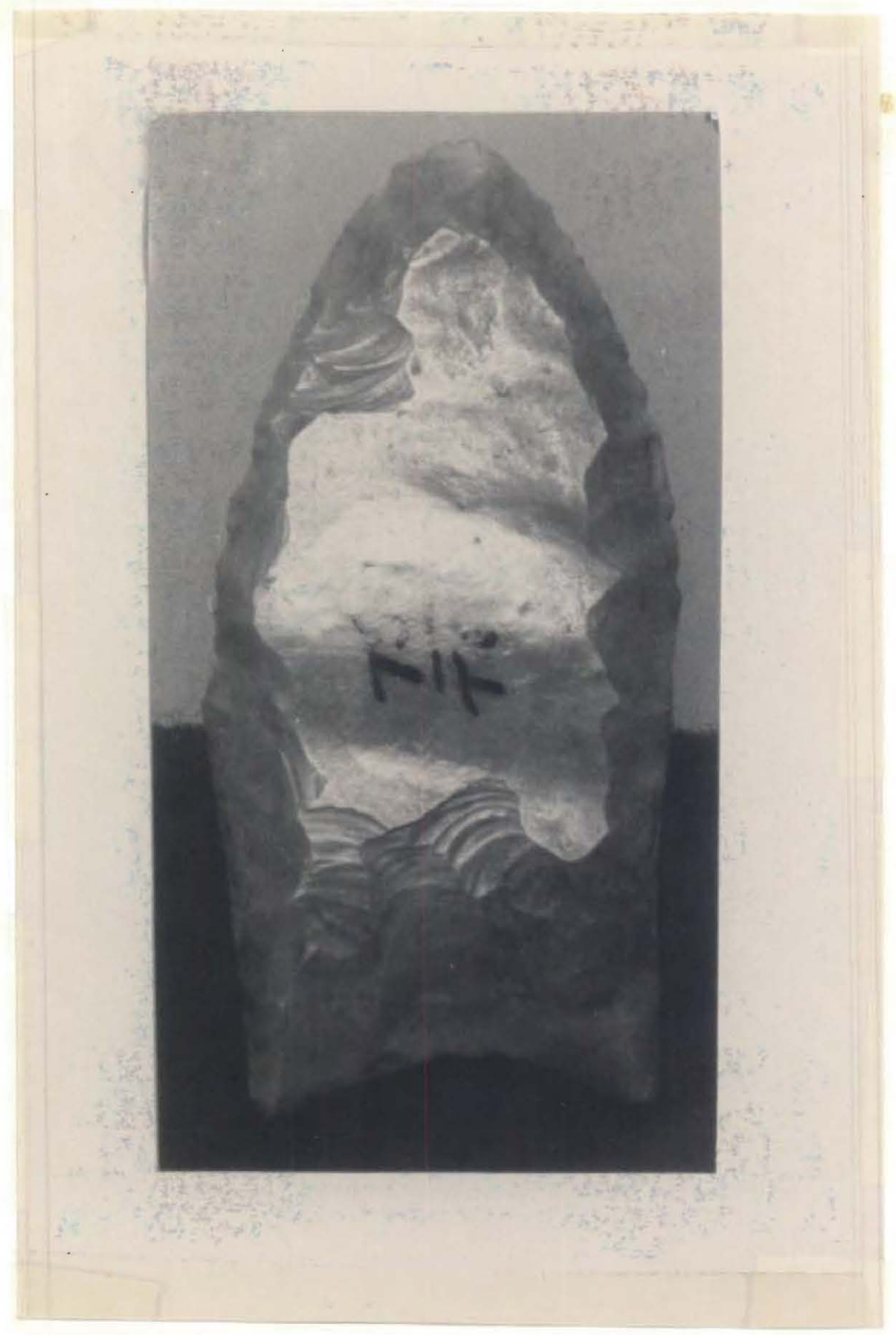

Figure 3. Lustrous Facet on Obverse Face of Specimen 758. This photo is similar to Figure $2 \mathrm{D}$, except view is slightly oblique to emphasize luster of remnant facet. 
from the horizontal axis; beveling extends about $4 \mathrm{~mm}$ from the edges. These lateral trimming scars are fairly deeply concave. Scars are generally converging in shape; a few are parallel-sided or expanding. Maximum scar length and width are both about $4 \mathrm{~mm}$. Reworking scars are similar to the original trimming scars at the juncture between the original and reworked edges, but they become larger and flatter toward the distal ends as the edge angle becomes more acute. The largest reworking flake scar is $9.2 \mathrm{~mm}$ wide and about $10 \mathrm{~mm}$ long and is oblique, with a stepped termination. Others are up to $4.7 \mathrm{~mm}$ long and $2.7 \mathrm{~mm}$ wide. Sanders (1990:47 and Figure 32c) discusses a point from the Adams site that has similarly beveled edges.

On the left side of the proximal area of this face is the remnant of a basal thinning scar removed by the flute, which is well-centered and ends in a shallow step fracture. The right edge of the flute has been removed by a long, narrow, basal thinning scar that curves to the left and expands, ending in an oblique, shallow step fracture continuous with and indistinguishable from the flute termination. This flute was probably made after the flute on the reverse face. This face shows very little evidence of basal pressure flaking after fluting. Only a few discontinuous, very small $(0.4 \mathrm{~mm}$ wide, $0.3 \mathrm{~mm}$ long), pressure flake scars are visible.

\section{Reverse face (Figure $2 F$ )}

This face lacks the lateral beveling seen on the other. Lateral trimming scars become progressively longer toward the midpoint of the specimen (the longest scar is $16.25 \mathrm{~mm}$ long and actually overreaches the midline). Maximum width of these is about 1.9-5.8 mm, and they are oriented transversely. Scars left by reworking of the distal end are laterally to obliquely oriented. Three narrow, parallel, oblique ribbon-like scars originate from the left edge (these are about 1.6-3.4 $\mathrm{mm}$ wide and up to $14.8 \mathrm{~mm}$ long, partly truncated by scars originating from the right edge).

The flute on this face was probably an initial one. This is based chiefly on the fact that the center of the basal edge has a section about $2.0 \mathrm{~mm}$ wide, minutely beveled by pressure flaking (or edge-raking) that extends $0.5 \mathrm{~mm}$ back from the edge. This is flanked on either side by heavily pressure-beveled edges with scars extending $2.0 \mathrm{~mm}$ back from the edge. This central section is thought to be the remnant of a basal protrusion or nipple set up for fluting the obverse face (compare with Sanders 1990:Figure 30c and Storck 1983:Plate 1a, b). The reverse-face flute itself is shallow and quite symmetrical, with parallel lateral edges unaltered by subsequent flaking. The termination is feathered and slightly oblique. 


\section{Modification}

The flat facet on the obverse side bears many fine striations in seemingly random orientation (longitudinal, transverse, and oblique). These are mostly straight, of varying length and depth, with a few appearing sinusoidal to slightly curved. They are easily visible at magnifications of $10 \mathrm{X}$ and above. Only a few striations appear on the surface of the flute or on other obverse flake scars, whereas on the facet they are abundant, suggesting they predate the actual manufacture of the point. Width of the striations was roughly estimated (using a microscope scale) at less than $0.03 \mathrm{~mm}$. Their origin is unknown, but it is not believed related to use of the point. Similar striations are visible on the reverse face, on the small facet remnant, on the flute, and on a few other flake scar surfaces.

This specimen shows only slight polishing on flake scar ridges and hollows; it is less well developed than on specimen 19 , probably because that specimen has a less vitreous luster. On the reworked edge sections, edge projections show moderate rounding at 50X, while reentrants are much more acute, usually showing only light rounding.

maximum length: $53.05 \mathrm{~mm}$ maximum width: $25.65 \mathrm{~mm}$ maximum thickness: $6.56 \mathrm{~mm}$ maximum flute-to-flute thickness: $4.50 \mathrm{~mm}$ length from base to point of maximum width: $22.66 \mathrm{~mm}$ length from base to point of maximum thickness: $27.50 \mathrm{~mm}$ basal width: $21.95 \mathrm{~mm}$ depth of basal indentation: $3.30 \mathrm{~mm}$ left edge angles: original: $60^{\circ}$ reworked: $48^{\circ}$

right edge angles: original: $55^{\circ}$ reworked: $45^{\circ}$

weight: 10.0 grams

obverse face (beveled): maximum length of flute: $14.70 \mathrm{~mm}$ (to end of scar 2) $16.40 \mathrm{~mm}$ (to end of scar 3 ) maximum width of flute: $9.72 \mathrm{~mm}$ (widest remaining part of scar 2) flute scars: 3 ? grinding on left edge: $22.75 \mathrm{~mm}$ from base reverse face: grinding on right edge: $26.72 \mathrm{~mm}$ from base maximum length of flute: $15.73 \mathrm{~mm}$ maximum width of flute: $14.00 \mathrm{~mm}$ flute scars: 1

Specimen 759 (medial fragment, Lucas Creek; Figure 4D-F)

This specimen is made of light gray Manning fused glass. Because the material has 


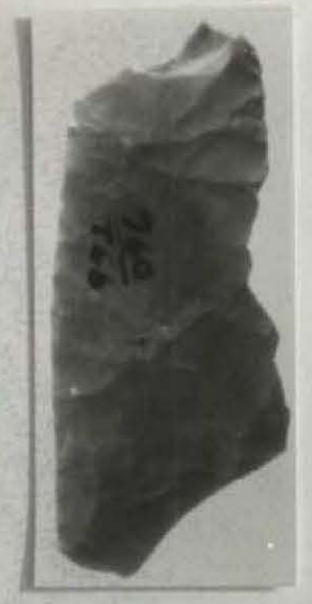

A

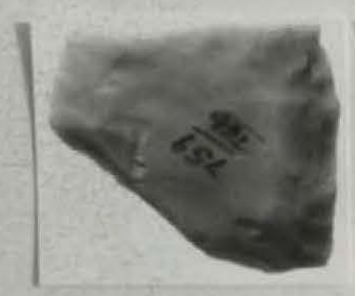

D

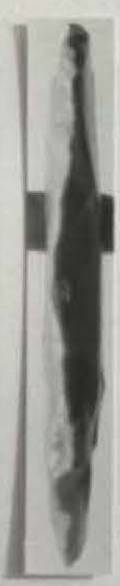

B

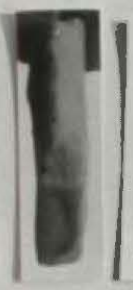

E

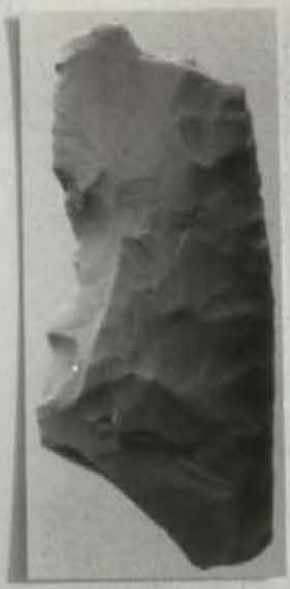

C

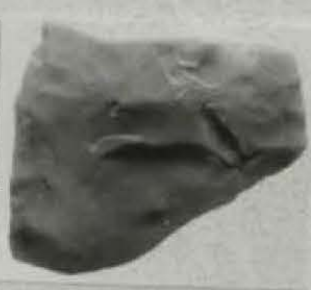

$\mathbf{F}$

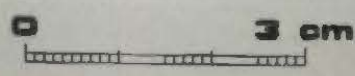

Figure 4. Clovis Point Medial Fragments from Lucas Creek. A, Specimen 760 obverse; B, Specimen 760 profile (obverse face to left); C, Specimen 760 reverse; D, Specimen 759 (Manning fused glass) obverse; E, Specimen 759 profile (obverse face to left); F, Specimen 759 reverse. 
a typically thick, gray (5Y 6/2) patination rind, flake scar and edge details are hard to see. The surface has the characteristic matte luster of Manning fused glass, and microscopic voids and gas bubbles pit the surface.

This small medial fragment has a transverse snap fracture at the distal end. The edges of this break show no modification except for extensive rounding, presumably by chemical weathering, and several small flake scars that originate from this snap facet as a platform, extending toward the proximal end on the reverse face, most of them ending in shallow step terminations. The proximal end has an oblique snap fracture. At least three small flake scars originating from the reverse face have removed part of the snap facet. Conceivably, these might have derived from pressure against a haft if the point broke but remained in the haft.

\section{Obverse face (Figure 4D)}

The obverse face appears to have at least one flute scar on its left side, and runs the length of the fragment. On the right side is an obliquely oriented, shallow step termination that either may be part of the same flute or a remnant of an earlier or later one. Because of the heavy weathering rind, its origin is ambiguous. Lateral trimming scars are converging to expanding in shape, up to $6.6 \mathrm{~mm}$ long, 3.7 to about $8.1 \mathrm{~mm}$ wide, and oriented transversely.

\section{Reverse face (Figure 4F)}

The reverse face has a well defined single flute with a shallow step termination that ends $11.20 \mathrm{~mm}$ short of the distal break. Just beyond the flute termination is a lateral thinning scar that originates at the left (viewed with the reverse face up) edge, passing well past the midline, to end in an oblique step termination (width of this scar is $5.05 \mathrm{~mm}$; length $24.2 \mathrm{~mm}$ ).

The lateral edges of this fragment show some crushing and only moderate rounding, but less rounding than would be expected considering the raw material.

\section{Modification}

Because of the weathering rind, no meaningful observations can be made.

maximum length: $27.20 \mathrm{~mm}$

maximum width: $31.47 \mathrm{~mm}$

maximum thickness: $6.34 \mathrm{~mm}$

maximum flute-to-flute thickness: $5.00 \mathrm{~mm}$

left edge angle: $42.5^{\circ}$ (both edges are beveled and edge angle measurements are accurate by comparison to the other specimens) 


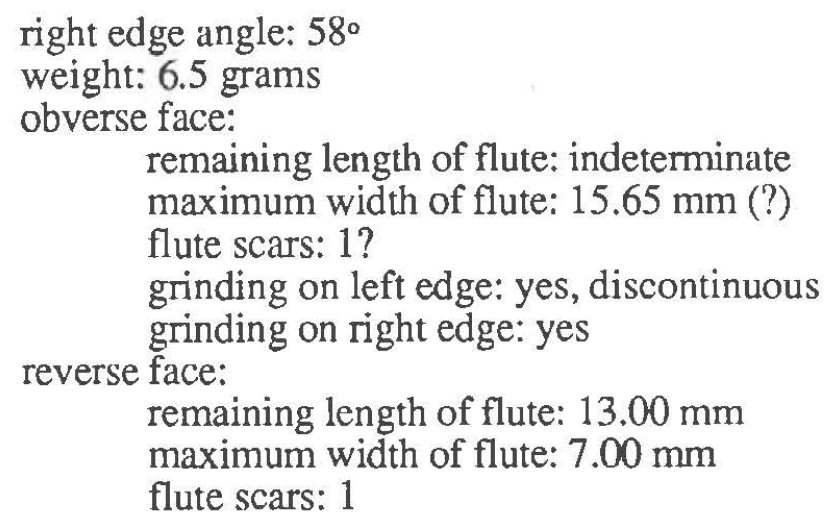

Specimen 760 (medial fragment, Lucas Creek; Figure 4A-C)

This specimen is made of medium (10YR 5.5/1) to light (2.5Y 7.5/1) gray chert with a vitreous luster and scattered, small, round, poorly preserved fossils (diatoms?). It is a badly damaged medial fragment of a Clovis point. The distal end has been removed by a crenated fracture, and the proximal end by an oblique fracture with a sinusoidal crosssection. Crenated fractures are usually thought to be due to excessive heating (Johnson 1979:25), but this point shows no potlidding, color change, or any other indication of heating. A large section of the right edge has been removed by a series of large shearing fractures originating from the obverse face. This irregular sheared edge has small, often stacked, invasive scars (varying from shallow to deep and notchlike) that may represent damage created by using the sheared edge for cutting. Most of these lie on the sheared face, but a good many small flake scars also lie on the opposite (obverse) face. Chandler (1990a:27) reports similar damage on a point from Comanche County. The snapped edge shows heavy grinding under magnification. Judging by the shortness of the flutes, this cannot be a remnant of the original basal edge. Perhaps it represents scrubbing of the snapped proximal edge as part of a failed attempt to rework the broken base of the point.

The reverse face has a large, curving facet with no ripple marks, similar to that on specimen 758; the same kinds of randomly oriented striations are also visible at 50X. This facet extends to within $1.8 \mathrm{~mm}$ of the left edge. Michael Collins (personal communication) suggested this might be a remnant of an outrepasse flake scar (Tixier 1974:19), but the facet seems too vestigal for positive recognition. The obverse face has a much smaller remnant of what may be a similar facet, near the distal end, plus a larger remnant where the catalog number is written. It too has a few microscopic striations.

\section{Obverse face (Figure 4A)}

The obverse face of this specimen is quite unusual; the right side of the face is mostly covered by five very large, flat flake scars that either originate from the sheared-off 
edge or from the original edge. Two of these scars are widely expanding, two others converging, and one is of indeterminate shape. One of the scars intrudes one of the others. The largest of these five flat (presumably soft-hammer percussion) scars has a maximum width of $14.09 \mathrm{~mm}$ and length of $13.66 \mathrm{~mm}$. The left edge of the obverse face is markedly different. It is covered with a series of parallel transverse flake scars, weakly converging or occasionally expanding in shape. These are deeper and more strongly ripple-marked than the ones on the right side, and are presumanly the result of pressure flaking. The maximum length of these is $8.93 \mathrm{~mm}$; maximum width about $6.9 \mathrm{~mm}$; average width about 2-4 mm.

The obverse flute is quite shallow, with a somewhat oblique, shallow step-fractured termination. It intrudes one of the large thinning scars on the right side. On the left side, a narrow ribbon-like scar has removed part of the left edge of the main flute (plus most of an earlier, similar scar that also traveled distally); it does not reach as far as the main flute, however (the surviving length is $14.35 \mathrm{~mm}$ ).

In the center of the proximal end, a large flute-like scar with a shallow stepped termination intrudes the main flute scar. This probably represents a second attempt at fluting the obverse side, but it conceivably could be damage resulting from proximal breakage. This scar has removed part of another that lies on the right side of the main flute scar. These parallel scars to the left and right of the main flute represent multiple flute removals (see Howard 1990:258).

\section{Reverse face (Figure 4C)}

On the reverse face, all but a short $(4.5 \mathrm{~mm})$ section of the left edge has been removed by the shearing break mentioned earlier. The remaining edge section has fairly heavy edge grinding. Most of the reverse face is covered by large soft-hammer thinning scars that reach to the midline or beyond. The longest one that is visible originates from the left edge and extends to within $7 \mathrm{~mm}$ of the opposite edge.

The right edge has many parallel, transverse, small trimming scars reaching on average less than $8 \mathrm{~mm}$ from the edge (range, $2.0-8.2 \mathrm{~mm}$ in length). Many of these are converging in shape, some are expanding, and with a couple ribbon-like (widths are 0.9$4.7 \mathrm{~mm}$ ). These are presumably pressure flaking scars.

There is a remnant of a single flute with a shallow step termination, intruded on the right side by two shallow flake scars originating from the proximal end. Since the base of the point is missing, it is not clear whether these represent multiple flute scars.

maximum length: $58.86 \mathrm{~mm}$

maximum width: $25.31 \mathrm{~mm}$

maximum thickness: $6.42 \mathrm{~mm}$ 


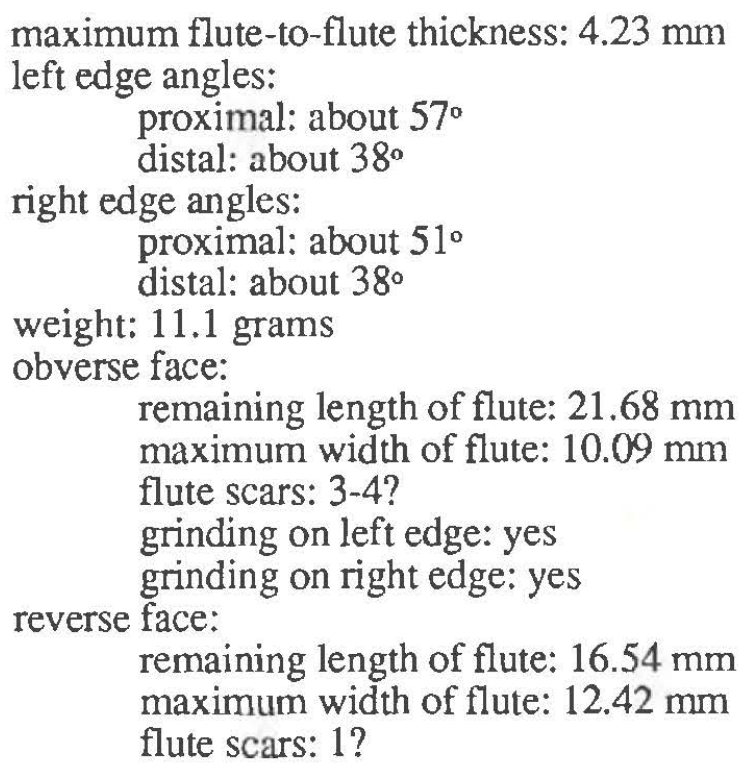

\section{CONCLUSIONS}

These four specimens illustrate some of the characteristics of Clovis points that have been addressed by several previous investigators. All four are finished points or, in Callahan's (1979:Figure 67) terms, Stage 9 bifaces. Two are complete, but reworked distally. The other two are medial fragments; of these, one (specimen 759) has a transverse snap just forward of the reverse face flute, similar to the impact break achieved by Frison (1989:Figure 9) while testing experimental Clovis darts on African elephant carcasses (see also Meltzer 1987:49). It also has an oblique basal snap fracture. The other medial fragment (specimen 760) has unusual snap, crenated, and shearing fractures that do not look like impact damage, but may be due to crushing, or loading of one face. None of these points appears to be heat-treated, although heat-treated Clovis points are occasionally seen (see Chandler 1990a:27, 1990b; Mitchell and Chandler 1990:21; Dragoo 1973:10-11, 14; Titmus and Woods 1991:129). Johnson (1989:120-121), on the other hand, maintains that intentional heat treatment of Clovis artifacts is uncommon, at least in the eastern United States. Better evidence for intentional heat treatment probably appears in later Paleoindian contexts (see Pavlish and Sheppard 1983).

The two complete points are rather short, 5.31 and $5.80 \mathrm{~cm}$ long, compared with an average length for unbroken Texas Clovis points of $7.42+/ 2.13 \mathrm{~cm}(5.29$ to $9.55 \mathrm{~cm}$; Meltzer 1987:Table 9 footnote). For comparison, Oklahoma Clovis points average $6.37 \mathrm{~cm}$ long (Hofman and Wyckoff 1991:30). This is undoubtedly a result of at least one episode of reworking on each point. Complete or nearly complete points that have not been reworked are often considerably longer (see Anderson and Tiffany 1972; Gramly 1993:51; Kelly 1988; Stanford and Jodry 1988; Wilson 1979:138). As an example, the points found 
at the Miami site were 7.6 and $11.6 \mathrm{~cm}$ long, respectively (Sellards 1938:1007). According to Collins (1990:74), five centimeters is approximately the threshold at which unbroken, resharpened Clovis points were discarded as unworthy of further use at knapping localities near raw material sources. Reworking can be recognized by inflections in the edge outline, or contrasting flake scar orientation, size, or degree of rippling; reworked edges can be detected by decreased edge angles, and sometimes the removal of previous edge grinding is suggested by an abrupt juncture between ground and unground edges.

Two of the specimens (758 and 760) retain remnants of facets from the original blank; these lack ripple marks, and are randomly striated. Howard (1990:257-258) attributes remnant facets to "various early processes, such as original cortex removal and preparation of large cores for large primary flake/blade removals...or, more frequently, the initial stages of reduction of bifacial preforms" and indicates they are characteristic of Clovis points, although Judge (1973:Table 15) reports them present in only five out of his 26 New Mexico Clovis points. The striations are not exclusively confined to the facets, but are more abundant there, suggesting they were mostly produced before reduction of the preform to final form. It is tempting to view these striations as evidence of abrasive contact between flake blanks during extended transport. However, it is more likely that prepared blanks would be carefully padded for transport, just as the Alyawara of Australia wrap blanks in bark pouches for transport from the quarry (Binford and O'Connell 1989:135136). Fagan (1988:394) reports "scratches in the flutes on both faces" of three basal fragments of obsidian Clovis points from Oregon. Frison (1991a:Figure 2.13b, 1991b:Figure 19.6b) reports an obsidian Clovis point from the Fenn Cache with longitudinal scratches on both flutes. Apparently these flute striations on obsidian Clovis points are a deliberate hafting feature, not to be confused with the random striations left from early reduction stages, as described above.

Flutes characteristically have very shallow stepped terminations. It is also common for the edges of the flute to be widened by small secondary flanking scars that originate at the base but do not extend as far as the end of the flute (Howard 1990:258). This is reminiscent of what Witthoft (1952:481-482) identifies as "triple channel flaking" at the Shoop site, but on the specimens reported here, the secondary flakes clearly were removed after the principal channel flake, not before. Previous investigators have suggested that two different methods were used to flute Clovis points: (1) percussion (perhaps direct) from a beveled base (Collins 1990:73), or (2) indirect percussion from a central basal protrusion (similar to but less acute than the central nipple used to flute Folsom points). This method is perhaps most clearly illustrated by an aborted specimen from Alabama described by Gustafson (1972:Figure 1 and 2), which follows the pattern proposed for the Shoop site. It 
is likely that the latter method was used on specimens 19 and 758, except that flanking "guide flakes" did not precede the removal of the flute.

I suspect that many of the Clovis points described in the literature as having hinged flute terminations really have shallow stepped terminations like the ones reported here. As the channel flake is driven off, it will terminate if the driving force for crack propagation falls below a critical value; the final crack that completes the step fracture is caused by bending (Cotterell and Kamminga 1987:700), perhaps by lateral pressure as the tip of the indirect percussor kicks the platform of the channel flake aside. On specimens 19 and 758 there are tentative hints that the initial flutes had feathered terminations, while the face to be fluted last had a stepped termination.

Three of the points are of raw material probably derived from the Edwards Plateau. The nearest source of this chert would either be the Balcones Escarpment, or old terrace gravels fringing major river drainages immediately downstream from the escarpment. In any case, a minimum transport distance of perhaps $290 \mathrm{~km}$ may be implied. Fields et al. (1991:9) report that Uvalde Gravels (late Miocene/Pliocene) of about 2-15 cm diameter, including some chert clasts, can be found in the Jewett Mine area, about $185 \mathrm{~km}$ due west of Lucas Creek-Cadell Island. Pleistocene Angelina and Neches River terrace gravels in the general vicinity of the Lucas Creek and Cadell Island localities are chert-poor and of small caliber. Chert gravels from the Neches drainage near the George C. Davis site (100 km to the west) are no larger than "very large pebbles" $(32-64 \mathrm{~mm})$ on the Wentworth scale (Brown 1970:Table 2-4). By Late Prehistoric times, a well-established system for importation of chert was in place at that site; Shafer (1973:57) suggests that some chert in nodule form was being imported from the Blackland Prairie zone. The Keven Davis blade cache from Navarro County (Young and Collins 1989) might suggest that export of Edwards chert toward the east was already being practiced by Clovis times (the cache is undated but specimens are morphologically similar to large Clovis blades). A group of Paleoindian artifacts (including two whole Clovis points), many of them made of Edwards chert, from the Neches River drainage at Lake Palestine (Perttula 1989:20 and personal communication) may be another indicator. What is not clear yet is whether Edwards chert was specifically sought through trade or deliberate long-distance quarrying expeditions, or whether chert collection was embedded in routine long-term mobility. For mobile foragers in the ethnographic record, as Binford (1980:Table 1) has shown, $290 \mathrm{~km}$ is well within the circuit distance covered in a single year, though not necessarily within the limits for the maximum radius of movement. For recent Nunamiut hunters, "a typical Nunamiut male will have traveled over more than 300,000 square kilometers in the normal course of hunting for game" (Binford 1983:I15). That is equivalent to a circle with a radius of about 
$310 \mathrm{~km}$. In the eastern United States, Tankersley (1991:Table 17.1) has documented Clovis points made of Knife River chert and Hixton quartzite transported anywhere from 730 to $2050 \mathrm{~km}$ from the source areas.

By Folsom times, artifacts made of Edwards chert routinely appear as much as 360 $\mathrm{km}$ to the north and $575 \mathrm{~km}$ to the northwest of the source area (Hofman 1991:Table 20.1). Although his discussion pertains to Folsom rather than to Clovis hunters, Hofman offers the most perceptive commentary published yet on the relationships between stone economizing, planning depth, and mobility. He argues that for specialized, highly mobile Folsom hunters, rates of lithic reduction and resharpening were heavily influenced by anticipated mobility. Do these concepts apply to the earlier Clovis tool users? Collins (personal communication) suggests that Clovis and Folsom economies were considerably different, and that Clovis hunters may have been significantly less mobile. If so, the instances of long-distance stone transport that we do see in Clovis assemblages may indicate something other than embedded procurement.

The Manning fused glass specimen is perhaps better regarded as made of "local" raw material. Although there are no known sources of fused glass closer than about $90 \mathrm{~km}$ away, the Manning Formation extends to the other side of the Angelina River valley, only about $8.5 \mathrm{~km}$ away, and it seems quite possible that there are unreported sources of fused rocks somewhere in this intervening area of Trinity County or Angelina County. According to Frison (1974), natural glasses are amenable to sourcing through neutron activation, although no one has tried it yet for Manning fused glass. While this fused glass has excellent chipping qualities, provided a large enough blank free of voids, folds, or impurities can be found, it is as brittle as other glasses, and it is not surprising that only a small medial fragment remains of what presumably was once a completed Clovis point.

\section{ACKNOWLEDGMENTS}

Special thanks to Dr. Russell Long, Sue Turner, and Paul Tanner for allowing me to study these specimens, and to Dr. Michael Collins for running the ultraviolet fluorescence check, for advice on Clovis lithic technology, and for reviewing this paper. Special thanks go to Bob Skiles for generously sharing information on Clovis points in local collections. Thanks also to Larry Banks for information and to Dr. Tim Perttula for reviewing a draft. 


\section{REFERENCES}

Anderson, Adrian D. and Joseph A. Tiffany

1972 Rummells-Maske: A Clovis Find-Spot in Iowa. Plains Anthropologist 17(55):55-59.

Banks, Larry D.

$1990 \quad$ From Mountain Peaks to Alligator Stomachs: A Review of Lithic Sources in the Trans-Mississippi South, the Southern Plains, and Adjacent Southwest. Memoir 4. Oklahoma Anthropological Society, Oklahoma City.

Binford, Lewis R.

1980 Willow Smoke and Dogs' Tails: Hunter-Gatherer Settlement Systems and Archaeological Site Formation. American Antiquity 45(1):4-20.

1983

In Pursuit of the Past: Decoding the Archaeological Record. Thames and Hudson, New York and London.

Binford, Lewis R. and James F. O'Connell

1989 An Alyawara Day: The Stone Quarry. In Debating Archaeology, by Lewis R. Binford, pp. 121-146. Academic Press, Orlando.

Brown, Kenneth $\mathrm{M}$.

1970 Some Observations on Lithic Resources at the George C. Davis Site. MS on file, Texas Archeological Research Laboratory, Austin.

1976

Fused Volcanic Glass From the Manning Formation. Bulletin of the Texas Archeological Society 47:189-207.

Callahan, Errett

1979 The Basics of Biface Knapping in the Eastern Fluted Point Tradition: A Manual for Flintknappers and Lithic Analysts. Archaeology of Eastern North America 7(1):1-180.

Chandler, C.K.

1990a Clovis Points from Comanche and Falls Counties. La Tierra 17(1):26-28.

1990b A Clovis Point from Kendall County, Texas. La Tierra 17(2):31-32.

Collins, Michael B.

1990 Observations on Clovis Lithic Technology. Current Research in the Pleistocene 7:73-74.

Collins, Michael B., Glen L. Evans, Thomas N. Campbell, Melissa C. Winans, and Charles E. Mear

1989 Clovis Occupation at Kincaid Shelter, Texas. Current Research in the Pleistocene 6:3-4.

Cotterell, Brian and Johan Kamminga

1987 The Formation of Flakes. American Antiquity 52(4):675-708.

Dragoo, Don W.

1973 Wells Creek -- An Early Man Site in Stewart County, Tennessee. Archaeology of Eastern North America 1(1):1-56. 
Fagan, John L.

$1988 \quad$ Clovis and Western Pluvial Lakes Tradition Lithic Technologies at the Dietz Site in South-Central Oregon. In Early Human Occupation in Far Western North America: The Clovis-Archaic Interface, edited by Judith A. Willig, C. Melvin Aikens, and John L. Fagan, pp. 389-416. Anthropological Papers 21. Nevada State Museum, Las Vegas.

Fields, Ross C., L. Wayne Klement, C. Britt Bousman, Steve A. Tomka, Eloise A. Gadus, and Margaret A. Howard

1991 Excavations at the Bottoms, Rena Branch, and Moccasin Springs Sites, Jewett Mine Project, Freestone and Leon Counties, Texas. Reports of Investigations No. 82. Prewitt and Associates, Inc., Austin.

Fredlund, Dale E.

1976 Fort Union Porcellanite and Fused Glass: Distinctive Lithic Materials of Coal Burn Origin on the Northern Plains. Plains Anthropologist 21(73, Pt. 1):207-211.

Frison, George C.

1974 The Application of Volcanic and Non-Volcanic Natural Glass Studies to Archaeology in Wyoming. In Applied Geology and Archaeology: The Holocene History of Wyoming, edited by Michael Wilson, pp. 61-64. Report of Investigations 10. Geological Survey of Wyoming, Laramie.

1989 Experimental Use of Clovis Weaponry and Tools on African Elephants. American Antiquity 54(4):766-784.

1991a Prehistoric Hunters of the High Plains. 2nd Edition. Academic Press, Orlando.

1991b The Clovis Cultural Complex: New Data from Caches of Flaked Stone and Worked Bone Artifacts. In Raw Material Economies Among Prehistoric Hunter-Gatherers, edited by Anta Montet-White and Steven Holen, pp. 32I-333. Publications in Anthropology 19. University of Kansas, Lawrence.

Gramly, Richard M.

1993 The Richey Clovis Cache: Earliest Americans Along the Columbia River. Persimmon Press Monographs in Archaeology, Buffalo.

Gustafson, John H.

1972 An Unfinished Fluted Point and Review of Fluted-Point Technology. Journal of Alabama Archaeology 18(1):47-54.

Heinrich, Paul V.

1987 Lithic Resources of Western Louisiana. Louisiana Archaeology 11:165190.

Hofman, Jack L.

1991 Folsom Land Use: Projectile Point Variability as a Key to Mobility. In Raw Material Economies Among Prehistoric Hunter-Gatherers, edited by Anta Montet-White and Steven Holen, pp. 335-355. Publications in Anthropology 19. University of Kansas, Lawrence. 
Hofman, Jack L., Lawrence C. Todd, and Michael B. Collins

1991 Identification of Central Texas Edwards Chert at the Folsom and Lindenmeier Sites. Plains Anthropologist 36(137):297-308.

Hofman, Jack L. and Don G. Wyckoff

1991 Clovis Occupation in Oklahoma. Current Research in the Pleistocene 8:2932 .

Howard, Calvin D.

1990 The Clovis Point: Characteristics and Type Description. Plains Anthropologist 35(129):255-262.

Ippolito, John

1983 A Cultural Resource Overview of the National Forests in Texas. United States Department of Agriculture, Forest Service, Southern Region, Lufkin.

Johnson, Jay K.

1979 Archaic Biface Manufacture: Production Failures, A Chronicle of the Misbegoten. Lithic Technology 8(2):25-35.

Johnson, Michael F.

1989 The Lithic Technology and Material Culture of the First Virginians: An Eastern Clovis Perspective. In Paleoindian Research in Virginia: A Synthesis, edited by J. Mark Wittkofski and Theodore R. Reinhart, pp. 95138. Special Publication 19. Archeological Society of Virgina, Richmond.

Judge, W. James

1973 Paleoindian Occupation of the Central Rio Grande Valley in New Mexico. University of New Mexico Press, Albuquerque.

Kelly, Thomas C.

1988 The Nockenut Clovis Point. La Tierra 15(4):7-18.

King, Elbert A., Jr. and Peter U. Rodda

1962 Fused Rocks in the Jackson Group (Eocene), Texas. Transactions of the Gulf Coast Association of Geological Societies 12:265-270.

Le Blanc, Raymond J.

1991 Prehistoric Clinker Use on the Cape Bathurst Peninsula, Northwest Territories, Canada: The Dynamics of Formation and Procurement. American Antiquity 56(2):268-277.

Meltzer, David J.

1987 The Clovis Paleoindian Occupation of Texas: Results of the Texas Clovis Fluted Point Survey. Bulletin of the Texas Archeological Society 57:27-68.

Mitchell, J.L. and C.K. Chandler

1990 Paleo-Indian Artifacts From the Medina River Area of Southern Texas. La Tierra 17(3):20-25.

Pavlish, L.A. and P.J. Sheppard

1983 Thermoluminescent Determination of Paleoindian Heat Treatment in Ontario, Canada. American Antiquity 48(4):793-799. 
Perttula, Timothy K.

1989 The Paleoindian Archaeological Record in Northeast Texas: Evidence from Avocational Collecting Activities. Current Research in the Pleistocene 6:1921.

Sanders, Thomas N.

1990 Adams: The Manufacturing of Flaked Stone Tools at a Paleoindian Site in Western Kentucky. Persimmon Press Monographs in Archaeology, Buffalo.

Sellards, E.H.

1938 Artifacts Associated With Fossil Elephant. Bulletin of the Geological Society of America 49:999-1010.

Shafer, H.J.

1973

Lithic Technology at the George C. Davis Site, Cherokee County, Texas. Unpublished Ph.D. dissertation, The University of Texas at Austin.

Stanford, Dennis J. and Margaret A. Jodry

1988 The Drake Clovis Cache. Current Research in the Pleistocene 5:21-22.

Storck, Peter

1983 The Fisher Site, Fluting Techniques, and Early Palaeo-Indian Cultural Relationships. Archaeology of Eastern North America 11:80-97.

Story, Dee Ann, Janice A. Guy, Barbara A. Burnett, Martha D. Freeman, Jerome C. Rose, D. Gentry Steele, Ben W. Olive, and Karl J. Reinhard

1990 The Archeology and Bioarcheology of the Gulf Coastal Plain. Research Series No. 38. Arkansas Archeological Survey, Fayetteville.

Tankersley, Kenneth B.

1991 A Geoarchaeological Investigation of Distribution and Exchange in the Raw Material Economies of Clovis Groups in Eastern North America. In Raw Material Economies Among Prehistoric Hunter-Gatherers, edited by Anta Montet-White and Steven Holen, pp. 285-303. Publications in Anthropology 19. University of Kansas, Lawrence.

Titmus, Gene L. and James C. Woods

1991 Fluted Points From the Snake River Plain. In Clovis: Origins and Adaptations, edited by Robson Bonnischsen and Karen L. Turnmire, pp. 119-131. Peopling of the Americas Publications. Center for the Study of the First Americans, Corvalis.

Tixier, J. (translation by M.H. Newcomer)

1974 Glossary for the Description of Stone Tools with Special Reference to the Epipalaeolithic of the Maghreb. Special Publication 1. Newsletter of Lithic Technology.

Wilson, Joseph B.

1979

A Preliminary Report on the Pin Oak Creek Site (41FY53): A Campsite with Clovis, Plainview, and Subsequent Artifacts in Fayette County, Texas. Bulletin of the Texas Archeological Society 50:135-140. 
Notes on Northeast Texas Archaeology, No. 2 (1993)

Witthoft, John 1952

A Paleo-Indian Site in Eastern Pennsylvania: An Early Hunting Culture. Proceedings of the American Philosophical Society 96(4):464-495.

Young, Bill and Michael B. Collins

1989 A Cache of Blades with Clovis Affinities from Northeastern Texas. Current Research in the Pleistocene 6:26-28. 